\title{
Identifying critical success factors in designing effective and efficient supply chain structures: A literature review
}

\author{
Khalid Mohummed Alomari ${ }^{a^{*}}$
}

${ }^{a}$ Assistant Professor, Business Department, College of Business and Economics Business, Al-Hussein Bin Talal University, Jordan

\section{CH R O N I C L E}

Article history:

Received October 28, 2020

Received in revised format

January, 15, 2021

Accepted January 252021

Available online

January 252021

Keywords:

Critical success factors

(CSFs)

Supply chain structures

Effective and efficient supply

chain

\begin{abstract}
A B S T R A C T
The present research mainly focuses on the review of existing literature on the topic of critical success factors (CSF) in supply chain structures. The main aim of this study is to identify the major critical success factors (CSF) that have been identified previously by academics and researchers during their research on the topics related to the discipline of supply chain management. The literature survey technique has been applied for the present research. This research is based on a critical review of seventy-three published studies on supply chain structures obtained from most important research databases by using the keywords related to supply chain structures such as barriers in the supply chain, critical success factors in supply chain structures. This study will not only contribute towards the existing literature on supply chain structures but will also help researchers to acknowledge the importance of critical success factors in supply chain structures. One of the major aspects of research regarding the supply chain is to reduce cost and that can only be done via effectiveness and efficiency in the processes, which depend on different variables at every level. The researchers have identified many critical success (CSF) factors in designing effective and efficient supply chain structures are a mutual partnership, executing communication and information expertise, support from senior management, human resource management, environmental uncertainty, value-addition process, business management, generating business culture, developing relationships between customer and supplier, logistics. The present research will also highlight the importance of different factors in achieving the effective and efficient in supply chain structures which enable organizations to not only reduce cost but also help them to achieve higher levels of customer satisfaction. This study will also be beneficial for managers as it will enable them to identify the critical success factors for their supply chain structures, keeping in view the nature and business environment of their organization.
\end{abstract}

\section{Introduction}

Most of the people got credit for the creation of critical success factors (CSF) such as Rockart (1979), but contrary to this belief the actual concept was first introduced by (Daniel, 1961). Rockart was one who extensively used it and thus polarized it. He defines CSF as the segments of business which have to be looked after for a business to be successful (Rockart, 1979). He coined the term "Key is" for these segments and these segments need to function well for business to succeed. To sum it up none of the businesses can be successful if these segments do not function efficiently. These segments need resources and attention from management. Leidecker and Bruno (1984), also defined line with (Rockart, 1979) and highlighted the importance of CSF. The long-term success of any business mainly depends upon the efficient and timely handling of CSF, such actions by management insure the survival and future success of the business (Islam, 2010). The organization adopt CSF as part of their strategy and thus rather than being evident they become invisible as they are incorporated into the norms

* Corresponding author

E-mail address: khaled@ahu.edu.jo (K. M. Alomari)

(C) 2021 by the authors; licensee Growing Science. doi: $10.5267 /$ j.uscm.2021.1.005 
and values of the organization because the success of the organization is mainly dependent upon them (Ab Talib, Hamid, \& Thoo, 2015; Meibodi \& Monavvarian, 2010; Van Nguyen, Nguyen, \& Bosch, 2017). The authors also note that key success factors and critical success factors are usually considered as the same and thus are interchangeably used in literature Khandelwal and Ferguson (1999) also endorses this notion followed by (Meibodi \& Monavvarian, 2010). The pioneering research in terms of using CSF in logistics management was conducted in the latter part of the 1990s initially by Chiu (1995), who assimilated CSF to logistics management framework to improve the distribution network, he emphasized on the planning of logistics network keeping in mind CSF along with the developing partnerships between different suppliers, analysis of investments and the important oversight function by top tier management Talib and Hamid (2014). His research was followed by and Korpela and Tuominen (1996) and Tate (1996); they also endorsed the role of CSF in logistics management.

In the 1960s the main focus of businesses was the retention of the customer along with creating the customer base which leads to the maximized profits. Chin, Tummala, Leung, and Tang (2004) states that in later decades the trends in businesses moved away from customer retention and companies focused upon providing customers with high-quality products at reasonable prices, by utilizing economies of scale. This also led to a focus on quality and concepts such as TQM, ISO, JIT came into existence with the singular focus of measuring and assuring the quality of the products and services being produced (Alomari, Mansour, Almohtaseb, Salah, \& Alshaketheep, 2020; Chandra \& Kumar, 2000). According to Li et al. (2005), with the advent of globalization at the start of 90's the market forces comped business to adopt new strategies which included a reduction in delivery time along with cost and targeting the right customers (Altekar, 2005) also holds similar views. The organizations were compelled to adopt partnership strategies to maintain their competitiveness rather than working alone when it came to managing the supply chain at both local and global levels. The $21^{\text {st }}$ century gave rise to issues such as competitiveness and financial sustainability, as supply chains of the organization became global (Gunasekaran \& Kobu, 2007). The successful supply chain structures were based upon recognition of customer satisfaction and reducing the cost, which helped organizations to maintain competitive prices and financial sustainability. This could be achieved by only considering value-adding activities from the supply chain and eliminating the others, resulting in a smooth flow of products and services from suppliers to end-users (Lee \& Chan, 2005).

The supply chain is considered the backbone of small as well as medium-sized businesses. As an efficient supply chain provides the financial and operational flexibility to these businesses, helping them to become sustainable (Chalmeta \& Santos-deLeón, 2020; Tannous \& Yoon, 2018). Technological advancements such as the use of artificial intelligence (AI) and the advent of big data have enabled organizations to increase the efficiency of their supply chain operations (Daneshvar Kakhki \& Gargeya, 2019). The adoption of such technologies has enabled them to not only achieve a competitive advantage but also to maintain this advantage as well(Huo, Han, \& Prajogo, 2016). Regardless of the nature, scale, or scope of organizations the main aim of the supply chain is to improve the efficiency in operations by reducing the cost, supplying the correct material to correct customers within minimum possible time, and cost. Its importance has been recognized by booth academic circles as well as practitioners. The scope of supply chain structures is universal as it encompasses the aspects such as procurement, logistics, operations, strategic management, and engaging customer at almost all levels of the organization (Robb, Xie, \& Arthanari, 2008) many academics such as (Chow et al., 2008; Corro, Singer, \& Donoso, 2007). Earlier researchers such as (Swafford, Ghosh, \& Murthy, 2006; Tan, Kannan, Handfield, \& Ghosh, 1999) had also concluded on similar notes.

According to Gunasekaran, Patel, and Tirtiroglu (2001), supply chain structures involve devising and organizing operational activities, securing purchasing and locating activities, manufacturing of products, and their components. Seuring and Müller (2008) pursuing finished and raw material inventory and completion of the manufacturing order and delivering them to the end-user within a timely and cost-effective (Squire, Burgess, Singh, \& Koroglu, 2006). In the context of gaining competitive advantage, Chow et al. (2008) note the progress of Zara, the span based clothing brand which was able to increase its product range by adding almost eleven thousand products to its existing product line by efficiently utilizing its supply Chain operations. As it can design, manufacture, and deliver the products to its six hundred global outlets in just a few days. Quesada, Rachamadugu, Gonzalez, and Martinez (2008) highlighted the positive correlation amongst the integration of supply chain structures with business objective create win-win situation organizations for both organizations and customers, ensuring quality of products/services, operational flexibility, and cost reduction, which are main objectives of supply chain management. Lambert and Cooper (2000) had earlier shed light on the three basic components the management of supply chain structures, network of the supply chain, and the processes involved in the supply chain, later on, Lambert et al. (2005) conducted further research and highlighted different aspects of supply chain structures and also affirmed their earlier findings.

The three main challenges identified by (Dulababu, Lakshmi, \& Girish, 2018; Robinson \& Malhotra (2005)) in terms of supply chain structures are First, development of confidence and relationship amongst the members of the supply chain; Second, identification of finest practices and their application in a coordinated manner; and third establishment of the latest information technology-based systems in a collaborative manner. Implementation of quality in supply chain structures and the application of technology in managing the supply chain is key to achieving success in business. Implementation deals with social aspects such as endorsement by supply chain partners, acceptance by employees, etc., meanwhile later tackles the technical aspects of implementing supply chain. On the contrary, Chen and Paulraj (2004) stress that based upon the theory of supply chain the main components can be classified into eight parts, they based their findings on analyses of 
almost four hundred academic articles. According to them, these components are the integration of logistics, relationship management of both suppliers and customers, the structure of the network, adoption of updated strategies, support and oversight of higher management, and use of information technology.

Globalization has put additional pressure on the business in the form of increased competition. Supply chain management can act as a tool to counter this pressure as it enables businesses to reduce costs and improve productivity along with quality at the same time. Productivity mainly relies on supply chain management, as it cuts production time and ensures quality. This happens as the right products are delivered in a timely cost-effective manner. In the global setting, the transparency of the supply chain management process is integral for the efficiency of supply chain management. This usually results in quality products that ensure additional demand for the products. The supply chain originates from the anticipation of demand and ends at the fulfillment of order and recording feedback of the end-users. This not only is a competitive advantage but this advantage is also sustainable.

The main aim of this study is to identify the critical success factors (CSF) required for designing effective and efficient supply chain structures. This aspect of supply chain management has hardly been explored by researchers. And only a limited number of researchers namely Koh, Gunasekaran, and Goodman (2011) Lu, Huang, and Heng (2006) have pinpointed out the never-ending stream of CSF in designing efficient supply chain structures.

The remainder of the research comprises a review of the literature relating to CSF in supply chain structures in section 2 , outlining the methodology approach in section 3, and lastly the conclusion of research in section 4 along with future direction for researchers.

\section{Literature Review and Identifying critical success factors in designing effective and efficient supply chains structures}

This section comprises a review of existing literature on the given topic. First and foremost, defining the concept of the efficient and effective supply chain, followed by the identification of CSF for designing such supply chains.

\subsection{Effective and Efficient Supply Chain Structures}

Management of supply chain structures consists of managing all thecomponents of which are joined to form the supply chain, starting from thesupplier or provider of the product, and ending at end users. The supply chainlinks the supplier to end-users by creating an interlocking mechanism amongstthe members of partners and a series of activities undertaken by them fromstart to finish (Alomari et al., 2020). This also involves the flow of monetary resourcesfrom end to start and flow of products from start to end. So, it encompasses theends of the process. It has been listed as one of the most important tools for thesuccess of any business by Gunasekaran et al. (2001) and one main toolfor achieving the corporate and business objectives. The main components of a supplychain include planning the activities, identifying the sources, manufacturingof products, distribution of products, and after-sales services such asmanaging returns. Each activity has different sets of risks, the propensity ofwhich ultimately affect the supply chain. According to Mentzer et al. (2001) supply chaincomprises coordinating the conventional activities of a business systematicallyat a strategic level, the strategies to cope up within and outside the businesswith partners of the supply chain. To improve the financial performance of thebusiness and its partners of the supply chain in both the long and short term. This definition is mostly in line with that of Cooper, Lambert, and Pagh (1997) who also held thatintegration of all the above-mentioned aspects formulates the SCM, and alsoemphasized the importance of supply chain structures for the success of anybusiness. One of the most important aspects is the integration of not onlyprocesses but the supply chain partners into the closely linked networks, whichbenefits all the participants of the supply chain in both the long and shortterm by improving their profitability and enhancing their competitiveness(Lambert \&Cooper, 2000).Christopher (1998), states that the market leadership mainly depends upon theefficiency of supply chain management, he highlights the two main criteria asleadership in terms of services and cost-effectiveness. The companies can increasereturns by lowering the cost of production and increasing the overall turnover. The cost of the supply chain is lowered by monitoring both internal andexternal factors. Internal monitoring includes monitoring of inventory, assessingproduction and supply lead times, assessing the opportunity cost of theseoperations. While external aspects include analyzing the feedback from thecustomers, managing after sales services (Christopher, 1999). Simchi-Levi, Kaminsky, Simchi-Levi, and Shankar (2003) holds that thecompetitive advantage can only be held by an organization which can focus theirattention on both internal and external aspects of supply chain along withclose monitoring of all levels of supply chain, by collaborating with the allstakeholders of supply chain ecosystem. The effective and efficient supply chain is a prerequisite for success inglobal markets. The conflict of interests within the organization's managersand supply chain partners results in the creation of uncertainties and unduerisks, these in term increase the cost while lowering the efficiency of thesupply chain, and also have a detrimental impact on the demand of the productsalong with revenues. Supply chain management enables organizations torationalize their supply chain function. Supply chain productivity is affectedby the extent of the supply channel. Compared with long medium, short-medium hasa positive impact on cost reduction and generates more revenue (Sidhu, Sidhu, \& Singh, 2011).

The administrative system of the supply chain allies has to turn out to be an essential part of making sure the productivity of the supply chain. According to (Jeszka,2014) the statistics, facts, and figures and information are exchanged in the supply chain through teamwork i.e., between vendors with dealers and logistics workers. The managerial aspects related to the 
flow of information and managerial behavior such as employee experience and IT systems are affecting the efficiency of supply chain administration. If the company's policies in the field of reverse logistics are suitable, it will have an encouraging impact on the ability of the supply chain, by doing so expenditure is savings (Jeszka, 2014). It is found that the design choices of products and services are related to supply chain administration. Modular design is linked to a freely coordinated supply chain, while the integrated design is linked to a closely coordinated supply chain Lau, Yam, Tang, and Sun (2010), that is, integrated design makes supply chain management more efficient and useful than modular design. Zhao et al. (2014) assume those products whose prices are dependent and demand fall.

$\mathrm{Xu}, \mathrm{Li}$, and $\mathrm{Wu}(2009)$ tested environmental ambiguity through DEA, which greatly affected the capability of the supply chain. The trust between allies plays a vital role in promoting commitment to supply chain dealings and improving supply chain competency. Based on experience, it has been determined that the stronger the trust between supply chain allies, the higher the responsibility. Furthermore, the company's faith and perceived satisfaction with its supply chain allies, the communication, and the reputation of the allies in the market are closely interrelated. Business administration mainly includes tasks such as management of resources, planning at all levels of the organization, monitoring of business activities, and implementing control activities to achieve the aims and objectives set by management. Ford and Mouzas (2010) described it as "a method of supervising inter-company networks. The rapid changes in customer needs, internalization of the market, and continuous changes in technology require companies to focus on enhancing the enterprising spirit and bring new innovative ideas, effort to obtain customer fulfillment by adding a lot of value to their products(Hung, 2010). Therefore, improving the execution of business techniques it is essential to increase corporate performance (Schiuma, Lerro, \& Linzalone, 2008), thereby improving corporate performance, that is, increasing effectiveness, efficiency, and capability (Thomas \& Griffin, 1996), which is also promoted by the company's marketing plan (Petersen, Handfield, \& Ragatz, 2005) advancement and innovation. Since innovation enables the accomplishment of the latest supply chain methods, goods, and services can quickly respond to customer desires and wants (Leavy, 2010), thus improving the effectiveness of supply chain structures.

\subsection{Identifying critical success factors in designing effective and efficient supply chains structures}

This part identifies critical success factors in designing effective and efficient supply chain structures.

Daniel (1961) can be considered as a pioneer in terms of research on the achievement aspect of the supply chain as he was the first one to highlight the importance of information systems in crisis management within the organization. He pointed out six aspects of the information system which make it successful and must be considered before design and implementing such a system. Anthony, Dearden, and Bedford (1980) highlighted three requirements for any such system when developing a management control system: "The control system must be modified for the particular enterprise in which the company runs and the precise strategies have been adopted; the key success factors must be ascertained. For a company to succeed, it must create a center of continuous attraction and attention from management and it must be prominent in the key variables reported to all management".

Probably the main and vital role comes from Rockart (1979), who believes that the key to success is the key to the expansion of an IT-based system. Research by Rockart mainly focuses on the development of the technique to examine major success factors. One of the main credits of Rockart (1979) was that he combined the concepts put forward by (Anthony et al., 1980; Daniel, 1961) generalized the CSF which can be universally applied to almost all organizations within the specific industry. These factors could be adopted by the organization based on their nature, location, and general environmental settings. Based on the literature review we identified below critical success factors in designing effective and efficient supply chain structures.

\subsubsection{Mutual Partnership}

As per Holweg, Disney, Holmström, and Småros (2005), the purpose of partnership in the supply chain is to form various forms of universal, clear, and compelling demand patterns. Besides, partnership in the supply chain is an important factor, and companies must integrate their consumers and dealers. This is consistent with Flynn, Huo, and Zhao (2010) that specified cooperation must engage both vertical (dealer customers) and horizontal (opponent) cooperation. Moreover, prosperous partnerships in the supply chain also provide many encouraging results, such as reducing costs, upgrading service competency and effectiveness, increasing profits, and allowing better operational adaptability (Glenn Richey Jr, Roath, Whipple, \& Fawcett, 2010).

The partnership in the supply chain cannot be curtained because it is hard to implement, as the lack of awareness and information about when who, or with whom to work in partnership and trusting the problems between partners can become an obstacle to success (Hong, Dobrzykowski, Park, Näslund, \& Hulthen, 2012). According to Hong et al. (2012), the basics of supply chain cooperation and enterprise are faith (visibility), mutual relationship, sharing of information, and honesty, and communication. These fundamentals are sustained by (Kim \& Rhee, 2012). 


\subsubsection{Executing Communication and Information Expertise}

The use of Information technology-based communication systems is a significant strategic component in supervising the supply chain. According to Handfield and Nichols, 1999, information and communication technology performs as a communicator and facilitator for product and process communication, while minimizing paperwork and delivery time. It also offers companies many opportunities to simplify communication and develop dealer/buyer feedback deficiencies. Therefore, the valuable development of information and communication technologies is vital for the expansion of fast and efficient systems.

Companies need a basic understanding of specific expertise. This is essential for preparing strategies and attaining expected improvement (Tummala, Phillips, \& Johnson, 2006). The quick growth in technology has brought many options for information technology software. Fawcett, Wallin, Allred, and Magnan (2009) mentioned that through effective use of technological infrastructures such as software packages, the Internet, and decision support systems, information can be easily transmitted in the supply chain. The Internet-based application development is an additional means used for processing information linked to the supply chain, for instance processing acquisition dealings with both in operations and strategy. Web-based Internet technologies can provide some examples, such as using e-mail/fax, internet, EDI, (EFT), Internet auctions, etc., which can perform supply chain management activities more effectively. The review time for companies using such systems can be reduced by almost two-thirds. The more use of the internet between the organizations has led to normal and more frequent communication amongst different organizations.

\subsubsection{Support from Senior Management}

Van Hoek, Chatham, and Wilding (2002) supply chain structures, management support is essential and Dinter (2013) holds the same view that the support from senior management is essential to the success of the information logistics strategy. Also, Power, Sohal, and Rahman (2001) believe that to make companies more responsive in the supply chain process, a participatory management style is needed. Moreover, fine communication, worker participation and appreciation, crossdepartmental interaction, and dedicated administrators are the signs of participation in participatory supply chain management. Furthermore, senior management support includes assigning resources, incentive mechanisms, and time, maintaining strategic procurement, developing strategic supplier affairs, and determination to adopt information technology (Tummala et al., 2006). Besides, Lin, Kuei, and Chai (2013) the communication, inspiration, obligation, and uninterrupted execution of the plan are the factors supporting the middle and upper management of the supply chain quality management (SCQM). One of the main CSF in supply chain structures is the oversight and support function by strategic management, for example, according to Ngai, Cheng, and Ho (2004), in addition to financial support and priority setting, the support of senior management can also come from the emotional and behavioral support of employees who resist change. Conversely, Fawcett, Magnan, and McCarter (2008) explained the difficulty of management and the foresight of top managers as obstacles to booming supply chain incorporation and the conclusion drawn that supply chain management is one of the top management's agenda, but there is a lack of understanding of the need to support supply chain management. Huam, Yusoff, Rasli, and Abd Hamid (2011) supports this result because company culture support can improve company completion, but frail company culture cannot.

\subsubsection{Human Resource Management}

Along with support at the organizational level, the manager handling supply chain needs to have the necessary skill set for the operations to be successful. Retaining such employees is difficult for companies and companies to face difficulties in hiring such employees, they tend to outsource the function of the supply chain. Hiring supply chain specialist is also considered as one important success factors in supply chain structures (Hidalgo \& López, 2009), the need for training cannot be overlooked, because training is of the utmost important factor of human resource management (HRM), because providing the best staffs with suitable training will advantage the supply chain process (Fawcett et al., 2008). Education and training are necessary because they will avoid the ERP implementation collapse. Besides, Gowen and Tallon (2003) illustrate the key impact of human resource management in supply chain management, that is, strengthening HRM through management support and staff engagement, and through useful training, which will alleviate supply chain execution obstacles and improve supply chain performance.

\subsubsection{Environmental Uncertainty}

According to Dwivedi and Butcher (2008), the natural ambiguity refers to natural problems in the product chain. Ettlie and Reza (1992) described it as a surprising modification in consumers, dealers, opponents, and technology. Yusuf (1995) said that government support plays a key part in the success of enterprises. The environmental insecurity is the main aspect in achieving strategic supply management structure. To enlarge in outsourcing actions in the industry has increased people's understanding of the importance of strategic supply management, thereby civilizing relationships between associations.

\subsubsection{Value-Addition Process}

Value-addition products are commodities that already exist andrequire minimal innovation. Bishop (1990) defines them as, value-addition can be explained as "the accumulation of manufacturing orexamining steps to goods, the customer sees it as enhancing its importance."clients mostly price products according to their perception, and if the productproves better 
than their perception, they will gain value. There are two mainfactors of value addition are the quality of products and their flexibility. Dramm (2000) held wooden products-basedindustry is mostly committed to attaining the maximum value at the lowest costthroughout the manufacturing process, thereby refining competency, superiority, and yield. Therefore, it is essential to incorporate the manufacturing systemas part of the value-addition process.

\subsubsection{Business Management}

Business administration includes leading, preparing, systematizing, observing, and controlling all implicated participants and actions in the company to attain aims and objectives. Ford and Mouzas (2010) describe it as "the method of managing systems among companies". With the rapid changes in the internalization of the marketplace, clients' demand, and the continuous changes in technology and expertise, companies require to focus on the betterment of competitiveness and trying to obtain consumer fulfillment by creating value-added products. Therefore, encouraging innovation and value addition to both products and business processes can be considered as essential functions of management. Besides, to improve manufacturing and business performance, process strategies can be used and managers see advertising strategy as an instrument to improve their returns (Petersen et al., 2005). Innovation and development are an integral part of any business as adopting and updating the latest innovations in product design, improvement of customer services are necessities for the long-term success of any business (Leavy, 2010).

\subsubsection{Generating Business Culture}

The main requirement for change is the company's environment and dedication, in the form of support by the employees of supply chain functions within an organization (Tan, Kannan, \& Handfield, 1998). Clear communication and time are required to establish a working relationship with suppliers, which is only possible if management at all levels shows its commitment and oversight function, without which it becomes almost impossible. The processes and functions need to be designed in such a way as to accommodate all partners of the supply chain (Cooper et al., 1997). It is significant for all levels of management to review the compatibility of their ethnicity and cultures when associations start to develop longterm dealings

The business culture must build up in the way of supporting supply chain members to solve problems and improve functions. After reaching a cooperation agreement, you need to work hard to solve the problem instead of transferring to a new colleague. a new cultural alter that needs to be made is a major devotion to supply chain structures. Supply chain structures must be included with other actions and procedures by genuinely distinguishing the ability of supply chain administration can companies attain achievable goals(Lester, 2000).

\subsubsection{Developing Relationships Between Customer and Supplier}

Establishing a joint venture is one of the most vital steps to establishand sustain the connection between consumers and dealers. To include allsuppliers in the supply chain plan of a strategic partner, we should firstcheck which suppliers have special strategic implications. The rising corporationneeds a lot of funds and can bring considerable threats (Stuart \&McCutcheon, 2000). Carter, Carter, Monczka, Slaight, and Swan (2000) also stresses on thedevelopment of symbiotic partnerships between different stakeholders of thesupply chain, these mainly include both internal and external partners of the supplychain network, this can be achieved when all of the members of this networkhave clear understanding of the functioning and objectives of each other.

According to Groves and Valsamakis (1998), many types andlevels of relationships exist between suppliers and customers. These dealingscan be considered as if they were a continuum from disagreement (fair trade) toa complete joint venture. Acceptance of the joint venture system is in linefundamental theory of supply chain management, one of the negativities suchrelationships arise when the procurement is solely based upon the price, ignoring other factors, such negativities do arise but are mostly temporary in thelong-term partnerships. A comprehensive partnership involves the sharing ofthreats, profits, and consistent improvement evaluations. The company can bebased on solo or various sources. A solo purchase requires a lot of confidenceand expectation. And only a small number of firms can establish true trustrelationships with dealers. The dealers must be confident that they will not beused by this arrangement.

\subsubsection{Logistics}

Rimienè and Grundey (2007) defined logistics as "the accountability of designing and managing systems to supervise the movement of raw materials, work-in-progress and completed product inventories and geographic location at the lowest whole price". A study by Autry, Zacharia, and Lamb (2008) held that logistics management should be focused on actions, logistics public accountability, strategic supply strategy, and coordination and collaboration of technology. Material supply usually engages a mixture of information flow, material treatment, making, wrapping, inventory, shipping, evidence, and deceleration, and sometimes safety (Czakon, Kawa, \& Scott, 2019). The complication of the supply is often sculpted, examined, and optimized through devoted imitation packages. Minimizing resources consumption may be a common inspiration for the whole supply segment (Richey Jr \& Davis-Sramek, 2020). 
Table 1

Summary of critical success factors (CSF) in supply chain structures

\begin{tabular}{|c|c|c|}
\hline & $\mathrm{CSF}$ & Authors \\
\hline 1 & Mutual Partnership & $\begin{array}{l}\text { Holweg et al. (2005), Flynn et al. (2010), Glenn Richey Jr et al. } \\
\text { (2010), Hong et al. (2012), Kim and Rhee (2012) }\end{array}$ \\
\hline 2 & $\begin{array}{l}\text { Executing Communication and Information } \\
\text { Expertise }\end{array}$ & $\begin{array}{l}\text { Handfield and Nichols, 1999, Tummala et al. (2006), Fawcett et } \\
\text { al. (2009) }\end{array}$ \\
\hline 3 & Support from Senior Management & $\begin{array}{l}\text { Van Hoek et al. (2002), Dinter (2013), Power et al. (2001), } \\
\text { Tummala et al. (2006), Ngai et al. (2004), Fawcett et al. (2008), } \\
\text { Huam et al. (2011) }\end{array}$ \\
\hline 4 & Human Resource Management & $\begin{array}{l}\text { Hidalgo and López (2009), Fawcett et al. (2008), Gowen and } \\
\text { Tallon (2003) }\end{array}$ \\
\hline 5 & Environmental Uncertainty & $\begin{array}{l}\text { Dwivedi and Butcher (2008), Ettlie and Reza (1992), Yusuf } \\
\text { (1995) }\end{array}$ \\
\hline 6 & Value-Addition Process & Bishop (1990), Dramm (2000) \\
\hline 7 & Business Management & Ford and Mouzas (2010),Petersen et al. (2005),Leavy (2010) \\
\hline 8 & Generating Business Culture & K.-C. Tan et al. (1998), Cooper et al. (1997), Lester (2000) \\
\hline 9 & $\begin{array}{l}\text { Developing Relationships Between } \\
\text { Customer and Supplier }\end{array}$ & $\begin{array}{l}\text { Stuart and McCutcheon (2000), Carter et al. (2000), Groves } \\
\text { and Valsamakis (1998) }\end{array}$ \\
\hline 10 & Logistics & $\begin{array}{l}\text { Rimienė and Grundey (2007), Autry et al. (2008), Czakon et al. } \\
\text { (2019), Robert Glenn Richey Jr and Davis-Sramek (2020) }\end{array}$ \\
\hline
\end{tabular}

\section{Methodology}

This article is based on relevant journals, books, reports, and other secondary materials. Literature analysis is the main method of this research. We reviewed seventy-three articles and books published in internationally well-known academic journals mainly related to supply chain management, logistics administration, operation administration, and other fields to discover the aspects that influence the efficiency of supply chain structures.

\section{Conclusion and future research}

This research aims to discover the main critical success factors (CSFs) in designing effective and efficient supply chain structures field by reviewing articles related to critical success factors and suggest mutual partnership, executing communication and information expertise, support from senior management, human resource management, environmental uncertainty, value-addition process, business management, generating business culture, developing relationships between customer and supplier, logistics. These CSF's have been explained in detail using the published literature in prior sections of the research.

Today's international business strategy has changed. The supply chain isnot restricted to manufacturing companies, but also includes service companies, which now focus on supply chain organization to ensure that they providecustomers with punctual services. Customers are reluctant to waste time waitingin line, which is why they search for substitute products where they can getquick service. In this case, the correct management of the value chain is verysignificant. The above aspects create value at all phases of the supply chain. They cannot examine anything except the company incoming to the market or evenbefore entering the market. They can progress the quality of products orservices by recognizing, evaluating, and ensuring the successful use of theseaspects.

This secondary research smooths the way for further study. First, interested researchers, academicians can cultivate research interest to examine the framework developed through literature review under practical conditions. Second, the research program can be outlined to see if the factors that make sure useful supply chain management contribute the same across the business. Lastly, a study can be outlined to see the impact (financial and non-financial) of effective supply chain management. Finally, to extra promote the knowledge system of supply chain management and CSF, prospect researchers should try to link CSF- supply chain management with company performance. The research on testing the CSF-SCM with good performance should be completed long ago and should be the primary agenda for future research. Such as Lippmann (1999) stated that previous research on CSF is only a list of possible CSFs, so no one should try to link CSF to company performance.

\section{References}

Ab Talib, M. S., Hamid, A. B. A., \& Thoo, A. C. (2015). Critical success factors of supply chain management: a literature survey and Pareto analysis. EuroMed Journal of Business, 10(2), 234-263.

Alomari, K. M., Mansour, A. M., Almohtaseb, A. A., Salah, A. A., \& Alshaketheep, K. M. (2020). Lean Six Sigma in Jordanian Organizations. International Journal of Economics \& Business Administration (IJEBA), 8(3), 429-447. 
Alomari, K. M., Maqableh, A. N. Y., Salah, A. A., Alshaketheep, K. M. I., \& abu Jray, A. A. (2020). Impact of Halal Digital Marketing on Consumer Behavior: Jordan's Perspective. International Journal of Economics \& Business Administration (IJEBA), 8(Special 1), 202-215.

Altekar, R. V. (2005). Supply chain management: Concepts and cases: PHI Learning Pvt. Ltd.

Anthony, R. N., Dearden, J., \& Bedford, N. M. (1980). Management Control Systems. Richard D. Irwin. Inc. Homewood, Illinois.

Autry, C. W., Zacharia, Z. G., \& Lamb, C. W. (2008). A logistics strategy taxonomy. Journal of Business logistics, 29(2), 27-51.

Bishop, J. (1990). In value-added manufacturing, customer calls the shots. Forest Industries, 117(6), $29-31$.

Carter, P. L., Carter, J. R., Monczka, R. M., Slaight, T. H., \& Swan, A. J. (2000). The Future of Purchasing and Supply: A Ten-Year Forecast 1. Journal of Supply Chain Management, 36(4), 14-26.

Chalmeta, R., \& Santos-deLeón, N. J. (2020). Sustainable Supply Chain in the Era of Industry 4.0 and Big Data: A Systematic Analysis of Literature and Research. Sustainability, 12(10), 4108.

Chandra, C., \& Kumar, S. (2000). Supply chain management in theory and practice: a passing fad or a fundamental change? Industrial Management \& Data Systems, 100(3), 100-114.

Chen, I. J., \& Paulraj, A. (2004). Towards a theory of supply chain management: the constructs and measurements. Journal of Operations Management, 22(2), 119-150.

Chin, K. S., Tummala, V. R., Leung, J. P., \& Tang, X. (2004). A study on supply chain management practices. International Journal of Physical Distribution \& Logistics Management, 34(6), 505-524.

Chow, W. S., Madu, C. N., Kuei, C.-H., Lu, M. H., Lin, C., \& Tseng, H. (2008). Supply chain management in the US and Taiwan: An empirical study. Omega, 36(5), 665-679.

Christopher, M. (1999). Logistics and Supply Chain Management: Strategies for Reducing Cost and Improving Service Financial Times: Pitman Publishing. London, 1998 ISBN 0273630490 (hardback) 294+ 1× pp: Taylor \& Francis.

Cooper, M. C., Lambert, D. M., \& Pagh, J. D. (1997). Supply chain management: more than a new name for logistics. The International Journal of Logistics Management, 8(1), 1-14.

Corro, H., Singer, M., \& Donoso, P. (2007). Internal supply chain management in the Chilean sawmill industry. International Journal of Operations \& Production Management, 27(5).

Czakon, W., Kawa, A., \& Scott, S. (2020). Network orientation of logistics service providers: the construct, dimensionality and measurement scale. International Journal of Logistics Research and Applications, 23(5), 474-492.

Daneshvar Kakhki, M., \& Gargeya, V. B. (2019). Information systems for supply chain management: a systematic literature analysis. International Journal of Production Research, 57(15-16), 5318-5339.

Daniel, D. R. (1961). Management information crisis. Harvard Business Review, 111-121.

Dinter, B. (2013). Success factors for information logistics strategy-An empirical investigation. Decision Support Systems, 54(3), 1207-1218.

Dramm, J. (2000). Results-driven approach to improving quality and productivity. Paper presented at the Proceedings: Wood Technology Clinic and Show Conference, 2000 March 15-17, Portland, OR.[Sl: sn, 2000]: 7 pages.

Dulababu, T., Lakshmi, R., \& Girish, B. (2018). Supply Chain Management: Opportunities and Challenges. Advances in Management, 11(4), 9-12.

Dwivedi, A., \& Butcher, T. (2008). Supply chain management and knowledge management: Springer.

Ettlie, J. E., \& Reza, E. M. (1992). Organizational integration and process innovation. Academy of Management journal, 35(4), 795-827.

Fawcett, S. E., Magnan, G. M., \& McCarter, M. W. (2008). Benefits, barriers, and bridges to effective supply chain management. Supply Chain Management: An International Journal, 13(1).

Fawcett, S. E., Wallin, C., Allred, C., \& Magnan, G. (2009). Supply chain information-sharing: benchmarking a proven path. Benchmarking: An International Journal, 16(2).

Flynn, B. B., Huo, B., \& Zhao, X. (2010). The impact of supply chain integration on performance: A contingency and configuration approach. Journal of Operations Management, 28(1), 58-71.

Ford, D., \& Mouzas, S. (2010). Networking under uncertainty: Concepts and research agenda. Industrial Marketing Management, 39(6), 956-962.

Gowen, C. R., \& Tallon, W. J. (2003). Enhancing supply chain practices through human resource management. Journal of Management Development, 22(1), 32-44.

Groves, G., \& Valsamakis, V. (1998). Supplier-customer relationships and company performance. The international journal of logistics management, 9(2), 51-64.

Gunasekaran, A., \& Kobu, B. (2007). Performance measures and metrics in logistics and supply chain management: a review of recent literature (1995-2004) for research and applications. International Journal of Production Research, 45(12), 2819-2840.

Gunasekaran, A., Patel, C., \& Tirtiroglu, E. (2001). Performance measures and metrics in a supply chain environment. International Journal of Operations \& Production Management, 21(1/2), 71-87.

Hidalgo, A., \& López, V. (2009). Drivers and impacts of ICT adoption on transport and logistics services. Asian Journal of Technology Innovation, 17(2), 27-47.

Holweg, M., Disney, S., Holmström, J., \& Småros, J. (2005). Supply chain collaboration:: Making sense of the strategy continuum. European Management Journal, 23(2), 170-181. 
Hong, P., Dobrzykowski, D., Park, Y. W., Näslund, D., \& Hulthen, H. (2012). Supply chain management integration: a critical analysis. Benchmarking: An International Journal, 19(4/5).

Huam, A. C. T. H. T., Yusoff, R. M., Rasli, A. M., \& Abd Hamid, A. B. (2011). Supply chain management: success factors from the Malaysian manufacturers perspective. African Journal of Business Management, 5(17), 7240-7247.

Hung, H.-M. (2010). Reconciling the paradox of supply-side and demand-side strategies in industrial innovation. Industrial Marketing Management, 39(2), 342-350.

Huo, B., Han, Z., \& Prajogo, D. (2016). Antecedents and consequences of supply chain information integration: a resourcebased view. Supply Chain Management: An International Journal, 21(6), 661-677.

Islam, R. (2010). Critical success factors of the nine challenges in Malaysia's vision 2020. Socio-Economic Planning Sciences, 44(4), 199-211.

Jeszka, A. M. (2014). Product returns management in the clothing industry in Poland. LogForum, 10(4).

Khandelwal, V. K., \& Ferguson, J. R. (1999). Critical success factors (CSFs) and the growth of IT in selected geographic regions. Paper presented at the Proceedings of the 32nd Annual Hawaii International Conference on Systems Sciences. 1999. HICSS-32. Abstracts and CD-ROM of Full Papers.

Kim, J., \& Rhee, J. (2012). An empirical study on the impact of critical success factors on the balanced scorecard performance in Korean green supply chain management enterprises. International Journal of Production Research, 50(9), 2465-2483.

Koh, S. L., Gunasekaran, A., \& Goodman, T. (2011). Drivers, barriers and critical success factors for ERPII implementation in supply chains: A critical analysis. The Journal of Strategic Information Systems, 20(4), 385-402.

Korpela, J., \& Tuominen, M. (1996). Benchmarking logistics performance with an application of the analytic hierarchy process. IEEE Transactions on Engineering Management, 43(3), 323-333.

Lambert, D. M., \& Cooper, M. C. (2000). Issues in supply chain management. Industrial Marketing Management, 29(1), 65-83.

Lau, A. K., Yam, R. C., Tang, E. P., \& Sun, H. (2010). Factors influencing the relationship between product modularity and supply chain integration. International Journal of Operations \& Production Management, 30(9).

Leavy, B. (2010). Design thinking-a new mental model of value innovation. Strategy \& leadership, 38(3).

Lee, H. L., \& Chan, C. K. (2005). The Supply Chain. Successful Strategies in Supply Chain Management, 50.

Leidecker, J. K., \& Bruno, A. V. (1984). Identifying and using critical success factors. Long Range Planning, 17(1), $23-32$.

Lester, M. (2000). An interview with Edith Kelly-Green: one on one. Journal of Supply Chain Management, $36(2), 2$.

Li, S., Rao, S. S., Ragu-Nathan, T., \& Ragu-Nathan, B. (2005). Development and validation of a measurement instrument for studying supply chain management practices. Journal of Operations Management, 23(6), 618-641.

Lin, C., Kuei, C. h., \& Chai, K. W. (2013). Identifying critical enablers and pathways to high performance supply chain quality management. International Journal of Operations \& Production Management, 33(3), 347-370.

Lippmann, S. (1999). Supply chain environmental management: elements for success. Corporate Environmental Strategy, $6(2), 175-182$.

Lu, X.-H., Huang, L.-H., \& Heng, M. S. (2006). Critical success factors of inter-organizational information systems-A case study of Cisco and Xiao Tong in China. Information \& Management, 43(3), 395-408.

Meibodi, L. A., \& Monavvarian, A. (2010). Recognizing critical success factors (CSF) to achieve the strategic goals of SAIPA Press. Business Strategy Series, 11(2).

Mentzer, J. T., DeWitt, W., Keebler, J. S., Min, S., Nix, N. W., Smith, C. D., \& Zacharia, Z. G. (2001). Defining supply chain management. Journal of Business logistics, 22(2), 1-25.

Ngai, E., Cheng, T., \& Ho, S. (2004). Critical success factors of web-based supply-chain management systems: an exploratory study. Production Planning \& Control, 15(6), 622-630.

Petersen, K. J., Handfield, R. B., \& Ragatz, G. L. (2005). Supplier integration into new product development: coordinating product, process and supply chain design. Journal of Operations Management, 23(3-4), 371-388.

Power, D. J., Sohal, A. S., \& Rahman, S. U. (2001). Critical success factors in agile supply chain management-An empirical study. International Journal of Physical Distribution \& Logistics Management, 31(4).

Quesada, G., Rachamadugu, R., Gonzalez, M., \& Martinez, J. L. (2008). Linking order winning and external supply chain integration strategies. Supply Chain Management: An International Journal, 13(4).

Richey Jr, R. G., \& Davis-Sramek, B. (2020). Supply Chain Management and Logistics: An Editorial Approach for a New Era. Wiley Online Library.

Richey Jr, R. G., Roath, A. S., Whipple, J. M., \& Fawcett, S. E. (2010). Exploring a governance theory of supply chain management: barriers and facilitators to integration. Journal of Business Logistics, 31(1), 237-256.

Rimiene, K., \& Grundey, D. (2007). Logistics centre concept through evolution and definition. Engineering economics, $54(4)$.

Robb, D. J., Xie, B., \& Arthanari, T. (2008). Supply chain and operations practice and performance in Chinese furniture manufacturing. International Journal of Production Economics, 112(2), 683-699.

Robinson, C. J., \& Malhotra, M. K. (2005). Defining the concept of supply chain quality management and its relevance to academic and industrial practice. International Journal of Production Economics, 96(3), 315-337.

Rockart, J. F. (1979). Chief executives define their own data needs. Harvard Business Review, 57(2), 81-93.

Schiuma, G., Lerro, A., \& Linzalone, R. (2008). Leveraging knowledge assets to improve new product development performances. Measuring Business Excellence. 
Seuring, S., \& Müller, M. (2008). From a literature review to a conceptual framework for sustainable supply chain management. Journal of Cleaner Production, 16(15), 1699-1710.

Sidhu, R., Sidhu, M., \& Singh, J. (2011). Marketing efficiency of green peas under different supply chains in Punjab. Agricultural Economics Research Review, 24(2), 267-273.

Simchi-Levi, D., Kaminsky, P., Simchi-Levi, E., \& Shankar, D. (2003). Managing the Supply Chain: Concepts, Strategies, and Case Studies: McGraw-Hill/Irwin, New York.

Squire, B., Burgess, K., Singh, P. J., \& Koroglu, R. (2006). Supply chain management: a structured literature review and implications for future research. International Journal of Operations \& Production Management, 26(7).

Stuart, F. I., \& McCutcheon, D. M. (2000). The manager's guide to supply chain management. Business Horizons, 43(2), 35-35.

Swafford, P. M., Ghosh, S., \& Murthy, N. (2006). The antecedents of supply chain agility of a firm: scale development and model testing. Journal of Operations Management, 24(2), 170-188.

Tan, K.-C., Kannan, V. R., \& Handfield, R. B. (1998). Supply chain management: supplier performance and firm performance. International Journal of Purchasing \& Materials Management, 34(3).

Tan, K. C., Kannan, V. R., Handfield, R. B., \& Ghosh, S. (1999). Supply chain management: an empirical study of its impact on performance. International Journal of Operations \& Production Management, 19(10).

Tannous, K., \& Yoon, S. (2018). Summarizing risk, sustainability and collaboration in global supply chain management. International Journal of Supply and Operations Management, 5(2), 192-196.

Tate, K. (1996). The elements of a successful logistics partnership. International Journal of Physical Distribution \& Logistics Management, 26(3).

Thomas, D. J., \& Griffin, P. M. (1996). Coordinated supply chain management. European Journal of Operational Research, 94(1), 1-15.

Tummala, V. R., Phillips, C. L., \& Johnson, M. (2006). Assessing supply chain management success factors: a case study. Supply Chain Management: An International Journal, 11(2).

Van Hoek, R. I., Chatham, R., \& Wilding, R. (2002). Managers in supply chain management, the critical dimension. Supply Chain Management: An International Journal, 7(3).

Van Nguyen, T., Nguyen, N. C., \& Bosch, O. J. (2017). Identifying key success factors in supply chain management for increasing the competitive advantages of Vietnamese coffee. Competitiveness Review: An International Business Journal, 27(5).

$\mathrm{Xu}$, J., Li, B., \& Wu, D. (2009). Rough data envelopment analysis and its application to supply chain performance evaluation. International Journal of Production Economics, 122(2), 628-638.

Yusuf, A. (1995). Critical success factors for small business: Perceptions of South Pacific entrepreneurs. Journal of Small Business Management, 33(2), 68.

Zhao, Y., Choi, T.-M., Cheng, T., Sethi, S. P., \& Wang, S. (2014). Buyback contracts with price-dependent demands: Effects of demand uncertainty. European Journal of Operational Research, 239(3), 663-673.

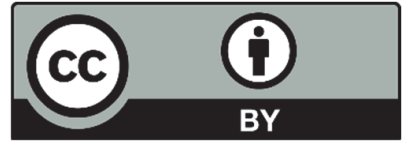

(C) 2021 by the authors; licensee Growing Science, Canada. This is an open access article distributed under the terms and conditions of the Creative Commons Attribution (CC-BY) license (http://creativecommons.org/licenses/by/4.0/). 